\title{
ESG-Risk Factors and Value Multiplier of Telecommunications Companies
}

\author{
Alexander Khorin $₫$ \\ Doctor of Economic Sciences, Professor of the "Accounting, analysis and audit" Department, Economic faculty, \\ Lomonosov Moscow State University, Moscow, Russia, anhorin@mail.ru, ORCID
}

\begin{abstract}
Arseniy Krikunov
Laboratory Assistant of the Educational and Scientific Laboratory of Network and Information Technologies in Economics of the Economic Informatics Department, Economic faculty, Lomonosov Moscow State University, Moscow, Russia, s.krikunof@yandex.ru, $\underline{\text { ORCID }}$
\end{abstract}

\begin{abstract}
The paper is devoted to the study of the impact of environmental, social responsibility and corporate governance (ESG) risk factors on the value of telecommunications industry enterprises expressed through the EV_EBITDA multiplier. The main goal was to assess the elimination of ESG risks from the standpoint of increasing the competitiveness of the company. The methodological basis of the study was the coordination of non-financial information of companies with their financial results. The paper implements the construction of a regression model within the framework of econometric modeling, the direction of which was proposed by A. Damodaran. The authors did not limit themselves to corporate information from one country, but identified five regions, such as the USA, the European Union, the UK, the rest of the developed countries (DEV), as well as the markets of developing countries (EM). The database was compiled on the basis of non-financial business activity parameters of 57 of the world's largest telecommunications companies as of 2021, where financial information is taken from the Bloomberg database, and the ESG risk coefficient of the rating of these companies is used from the Sustainalytics research center. The result of the study was that there is a stable relationship between the risk of the ESG rating and the EV/EBITDA parameter characterizing the cost of capital - that is, the lower the risk, the greater the cost of capital. For different country groups, the result was obtained with varying degrees of confidence: for "other developed countries" with a high 5\% significance level, for European countries with a 10\% level, for the USA, the insignificance of the coefficient is associated with a small sample size, and for developing country markets the coefficient is insignificant. The novelty of the results obtained lies in the use of a metric approach to confirm the stable dependence of ESG risk factors on the EV/EBITDA cost multiplier. The results obtained allow us to make a generalized conclusion that the elimination of ESG risks contributes to the growth of the company's competitiveness, where the results of the study are able to encourage companies to consider the disclosure of non-financial information as an important indicator of long-term sustainability. When ESG is considered as an integral factor in the future activity of the company, the end result is its higher evaluation by stakeholders.
\end{abstract}

Keywords: ESG risk factors, value multiplier, telecommunications companies, sustainable development, firm competitiveness

For citation: Khorin, A., Krikunov, A. ESG-risk factors and value multiplier of telecommunications companies. Korporativnye finansy $=$ Journal of Corporate Finance Research.2021;15(4):56-65. doi: https://doi.org/10.17323/j.jcfr.20730438.15.4.2021.56-65 
Environmental, social responsibility and corporate governance factors become integral to operating of both large and small enterprises (SME). At the same time the above factors involve rather tangible risks and opportunities which may influence corporate operations directly in the short and long term. In general, it is necessary to deal with corporate social responsibility (CSR) of an economic entity where ESG is not an abstract set of non-commercial aspects of corporate operations, but rather provisions stated in various CSR standards (voluntary at the moment) which a company has to follow and add to non-financial reports if it aims at sustainable development. It is not surprising that at present the notion of ESG occurs when dealing with consumers as well as investors and a wide range of concerned parties.

In each national economy the telecommunications industry is defined as a special segment of the service industry [1]. This industry is characterized by a high competition and rapid growth of telecommunication networks which makes companies pertaining to this industry rethink constantly their role in the market and implement up-to-date profit generating business models. Our survey of academic literature dedicated to the research topic which included use of information from ResearchGate shows lack of academic research of influence of such relevant factors as ESG factors on the telecommunications industry and risks related to it [2]. Risks in the telecommunications industry are also difficult to assess because there are no methodologies which forecast the threats for such services, and it costs billions of dollars to communications providers [3].

The types of risks from the point of view of their management (ERM) have been classified before for the telecommunications industry in paper [4] where the authors distinguish the following risks: reputational risk, competition risk, requirements compliance risk, technical risk, health risk, country risk, asset impairment risk, liquidity risk, currency risk, counterparty risk, interest rate risk, equity risk, corporate governance risk, human resource risk, repayment risk, market risk, weather risk, fraud risk. As we see, ESG risks have not been classified into a separate group before. It was assumed that although unconventional risks could have an actual impact on corporate financial performance they were considered to be incidental risks, consequently, non-financial ones [5].

Nevertheless, risk management becomes increasingly important for ensuring a long-term efficiency based on protection of interests of concerned parties, integration of economic, competitive, social and environmental achievements and sustainable development [6; 7]. So, McShane [8] uses the finance services industry to analyze the best practices in risk assessment methods while Monda and Giorgino [9] point out limitations in searching for the methods of risk quantitative evaluation in other industries, such as telecommunications. The matter is that recent studies show that companies which meet the ESG requirements have a better management, take more care of the environment and sustainable development, have a lower income volatility and have access to cheaper cash funds [10].
The paper by Friede [11] investigated over 2,000 empirical studies dedicated to disclosure of ESG information and corporate operations and revealed that $90 \%$ of studies pointed out a positive relation between ESG compliance and operational performance. As part of proving the interrelation between ESG factors and operational performance a sample of 6,151 observations from the Chinese stock market from 2007 to 2015 showed that social contribution improves response to share prices while an additional analysis shows that corporate governance also improves the extent of disclosure about social contributions of companies [12].

In another research Buallay [13] studies banks in developed and emerging markets and obtains mixed results of ESG influence on performance. It has been established that environmental disclosure has a positive impact on such performance while CSR disclosure in general shows a negative similar relation. Besides, ESG implementation solely for the purpose of reduction in expenditure on loans may eventually contradict the sustainable development concept if companies fail to understand the synergy of their own ESG efforts and the way in which such synergy creates value for their shareholders [14].

At the same time the results on the basis of data on 104 transnational enterprises from Peru, Columbia, Brazil, Chile and Mexico from 2011 to 2015 indicate that a negative relationship between ESG evaluation and financial performance is observed even when analyzed separately [15]. The results obtained on a sample of French companies pertaining to the SBF 120 index from 2003 to 2011 are illustrative of a negative relation between ESG and Tobin's $Q$ for the industries sensitive to the environment [16]. The results of a sample comprising developed countries from a study of 882 banks for the period of 2008 to 2019 show that ESG evaluations are associated negatively to the banks' performance indicator. Apart from that, banks have a smaller competitive advantage when they use their resources for social programs and initiatives (ESG and Tobin's Q) [17].

However, few studies are dedicated to the relation of competitive advantages of a company and its ESG compliance. Some researchers consider competitive advantage as company's ability to gain more economic profit in comparison to its competitors [18]. Results of a recent research of 20 largest pharmaceutical companies for 2014 and 2016 allowed to make a generalized conclusion that useful information obtained on the basis of reconciliation of structured data of financial and non-financial reports (from the Global Initiative database related to reports) facilitates improvement of business activity [19]. As a result of the research the general position of 5 socially responsible companies moved up to the $8^{\text {th }}$ and $6^{\text {th }}$ position in the Index of access to medicines. The results of comparing the growth rate of their total revenue, capitalization and long-term capital was positive in comparison to the growth rate of the quality of disclosure of non-financial indicators by them. Such interrelation was the strongest for raising long-term capital followed by growth of capitalization and at the same time it was the weakest for revenue growth. 
Taking into consideration Russian achievements and western studies of fundamental and applied sciences it should be noted that a modern financial expert is increasingly integrated in the Big Data technology. Use of Big Data not just in the financial sector but in general is a logical consistent pattern of technical and scientific advance of recent decades. It is important to state that in spite of a significant change of situation in the recent years the companies still aim at increase of their value, improvement of their investment attractiveness, development and business expansion [20].

Further, we analyze a wide range of complex financial and non-financial parameters of business activity of 57 world top telecommunications companies. We took financial information from the Bloomberg database. We used the ESG risk coefficient of the rating of these companies from the Sustainalytics research center as a parameter characterizing social and environmental responsibility [21].

In order to establish the dependence of the cost of capital of companies on their ecological parameters we used the model offered by A. Damodaran according to which the regression equation is as follows:

$$
\begin{aligned}
& \text { EV_EBITDA=a1·EBITDA_3Y_GROWTH + } \\
& \text { a2·DEPR_EBITDA + a3·CAPEX_EBITDA + } \\
& + \text { a4 } \cdot \text { NWC_EBITDA + a5, }
\end{aligned}
$$

where the variables EV_EBITDA $=$ EV / EBITDA are the cost multiplier which shows the value of business in EBITDA. The matter is that EBITDA (earnings before interest, taxes, depreciation and amortization) is indicative of estimated cash profit which accrues to and may be distributed among shareholders and debtholders. EV is the market value of business where the Enterprise value = market capitalization + net debt value. This multiplier is the most stable and accurate one for assessment of telecommunications companies' value because it does not depend fun- damentally on the debt load level unlike, for example, on Price/Earnings $(\mathrm{P} / \mathrm{E})$. In the multipliers DEPR_EBITDA = Depr/EBITDA, Depr is depreciation, CAPEX_EBITDA = CAPEX//EBITDA, CAPEX is investment in fixed assets, NWC_EBITDA = delta NWC/EBITDA, delta NWC is investment in working capital.

As long as companies operate in various parts of the world this factor has to be taken into consideration as well. For this purpose, we introduced slack variables which equal 1 if a company operates in a certain region (or country) and 0 - otherwise. The matter is that a limited number of observations prevents us from taking into consideration all country-related differences, therefore we defined five regions: the USA (US), the EU (EU), Great Britain (UK), other developed countries (DEV), markets of emerging countries (EM).

Thus, new variables were added to equation (1) and the final regression equation is as follows:

$$
\begin{aligned}
& \text { EV_EBITDA }=\text { b1 } \text {.EBITDA_3Y_GROWTH+ } \\
& \text { + b2.DEPR_EBITDA + b3.CAPEX_EBITDA + } \\
& \text { + b4.NWC_EBITDA + b5.ESG_Risk_RTG+ } \\
& \text { + b6_us. COUNTRY_GROUP_US + b6_eu. } \\
& \text {.COUNTRY_GROUP_EU + b6_uk. } \\
& \text {.COUNTRY_GROUP_UK + b6_dev. } \\
& \text {.COUNTRY_GROUP_DEV + b6_em. } \\
& \text {.COUNTRY_GROUP_EM. }
\end{aligned}
$$

The constant is eliminated because all slack variables are used (to simplify interpretation of possible results). Then we eliminated the lines which did not contain all necessary data for calculation and the data related to the companies which shares' value fluctuated greatly or which had implemented large transactions of purchase and sale of shares. The results of calculations of model (2) applying the one-step least square method were obtained in an application software package for econometric modeling GRETL (Table 1).

Table 1. One-step least square method, GRETL package

Model: least square method, observations 1-57 were used

Dependent variable: EV_EBITDA

Robust estimators of standard errors (adjusted to heteroscedasticity), version $\mathrm{HC1}$

$\begin{array}{lllll} & \text { Coefficient } & \text { Standard error } & \text { t statistics } & \text { P value } \\ \text { EBITDA_3Y_GROWTH } & -0.810515 & 0.386598 & -2.097 & 0.0414^{* *} \\ \text { DEPR_EBITDA } & -0.185089 & 2.85702 & -0.06478 & 0.9486 \\ \text { CAPEX_EBITDA } & 2.17957 & 1.65215 & 1.319 & 0.1935 \\ \text { NWC_EBITDA } & 0.149444 & 0.991101 & 0.1508 & 0.8808 \\ \text { COUNTRY_GROUPED_DEV } & 13.1554 & 1.77483 & 7.412 & 1.94 \mathrm{e}-09^{\star * *} \\ \text { COUNTRY_GROUPED_EM } & 13.5044 & 2.07343 & 6.513 & 4.48 \mathrm{e}-08^{\star * *} \\ \text { COUNTRY_GROUPED_EU } & 12.7619 & 1.64695 & 7.749 & 6.05 \mathrm{e}-010^{\star * *} \\ \text { COUNTRY_GROUPED_UK } & 11.7424 & 1.88479 & 6.230 & 1.21 \mathrm{e}-07^{\star * *} \\ \text { COUNTRY_GROUPED_US } & 16.0704 & 2.08792 & 7.697 & 7.25 \mathrm{e}-010^{\star * \star} \\ \text { ESG_RISK_RTG } & -0.181865 & 0.0756335 & -2.405 & 0.0202^{\star *}\end{array}$




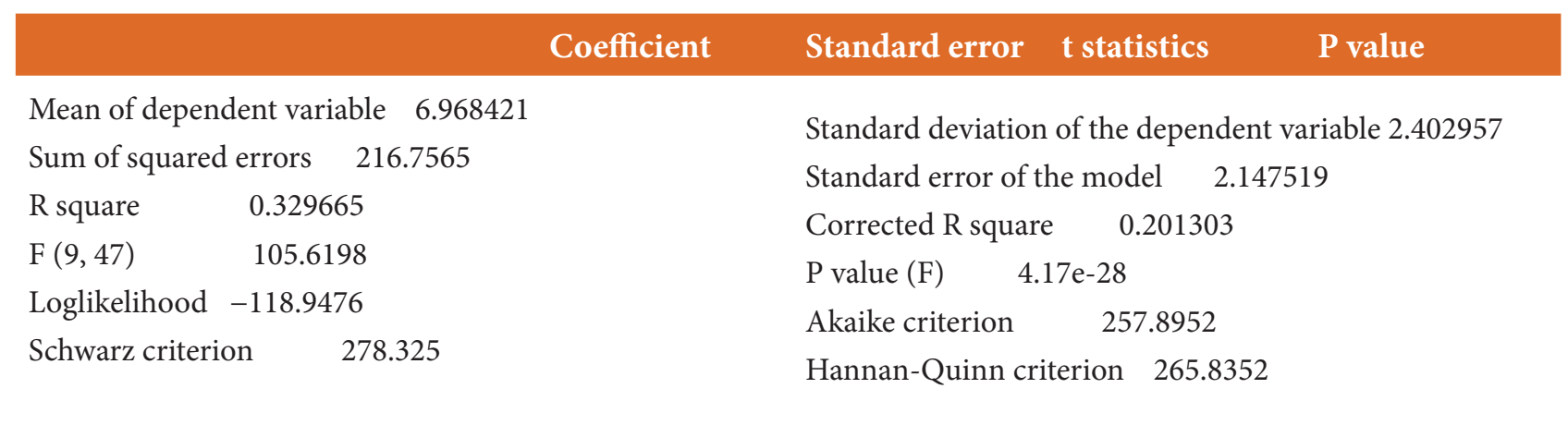

A low p value was obtained for variable 6 (DEPR_EBITDA)

The Ramsey test (RESET) -

Null hypothesis: adequate specification

Test statistics: F $(2,45)=1.37988$

$\mathrm{p}$ value $=\mathrm{P}(\mathrm{F}(2,45)>1.37988)=0.262048$

Results of the test of equation significance: $\mathrm{P}$ value $(\mathrm{F})=$ $4.17 \mathrm{e}-28$ is low, consequently, the equation is significant. The Ramsey test shows that the null hypothesis is correct and the model specification is not rejected. As long as the model has no constant, in order to ensure that the obtained value of the correlation coefficient $\mathrm{R}^{2}$ is correct we are going to verify what happens if we eliminate the parameter b6_uk.COUNTRY_GROUP_UK and introduce a constant. The values of $\mathrm{R}^{2}$ and corrected $\mathrm{R}^{2}$ have not changed. The calculation results show that the variable ESG_RISK_ RTG is significant at a $5 \%$ level and negative. This variable is interpreted as a risk and the lower its value the "greener" (environmentally benign) and socially more responsible is the company. A negative value of b5 means that the "green- er" and socially more responsible the company the greater EV/EBITDA is, i.e. the bigger the company value with the same profit.

The assumed model shows just $21 \%$ of the corrected correlation coefficient $\mathrm{R}^{2}$, i.e. it explains the behaviour of the dependent variable EV_EBITDA just by $21 \%$. In light of this we made calculations of the model by regions, i.e. separately for emerging markets, other countries, the EU and Great Britain. At the same time the data set comprises only companies of the abovementioned regions while slack variables have not been introduced (in actual fact, b6 is equivalent to the constant).

See the calculation results for all companies and emerging markets in Table 2.

Table 2. Least-squares estimate of the modified model, GRETL package

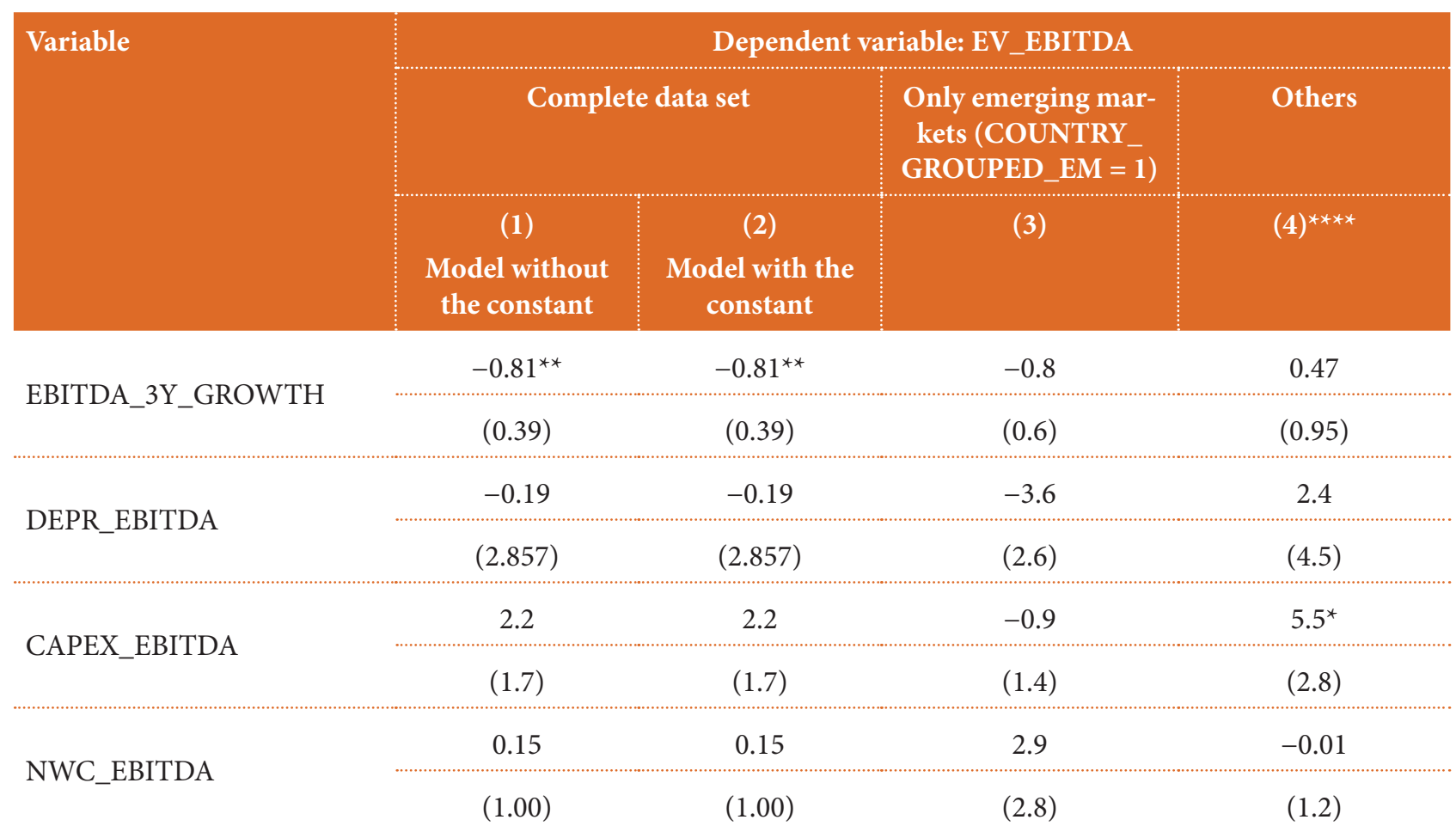




\begin{tabular}{|c|c|c|c|c|}
\hline \multirow{3}{*}{ Variable } & \multicolumn{4}{|c|}{ Dependent variable: EV_EBITDA } \\
\hline & \multicolumn{2}{|c|}{ Complete data set } & \multirow{2}{*}{$\begin{array}{l}\text { Only emerging mar- } \\
\text { kets }(\text { COUNTRY_ } \\
\text { GROUPED_EM }=1 \text { ) } \\
\text { (3) }\end{array}$} & \multirow{2}{*}{$\begin{array}{l}\text { Others } \\
(4)^{* * * *}\end{array}$} \\
\hline & $\begin{array}{l}\text { (1) } \\
\text { Model without } \\
\text { the constant }\end{array}$ & $\begin{array}{l}\text { (2) } \\
\text { Model with the } \\
\text { constant }\end{array}$ & & \\
\hline \multirow{2}{*}{ COUNTRY_GROUPED_EM } & $13.5^{\star * *}$ & $-2.6^{* * *}$ & & - \\
\hline & $(2.1)$ & $(0.8)$ & & \\
\hline \multirow{2}{*}{ COUNTRY_GROUPED_EU } & $12.8^{* * *}$ & $-3.3^{* * *}$ & & $-2.7^{* * *}$ \\
\hline & $(1.6)$ & $(0.9)$ & & $(0.7)$ \\
\hline \multirow{2}{*}{ COUNTRY_GROUPED_UK } & $11.7^{\star * \star}$ & $-4.3^{* * *}$ & & $-4.1^{\star * *}$ \\
\hline & $(1.9)$ & $(0.9)$ & & $(0.8)$ \\
\hline \multirow{2}{*}{ COUNTRY_GROUPED_US } & $16.07^{\star * \star}$ & & & - \\
\hline & $(2.088)$ & & & \\
\hline \multirow{2}{*}{ ESG_RISK_RTG } & $-0.18^{* *}$ & $-0.18^{* *}$ & $-0.46^{* * *}$ & -0.11 \\
\hline & $(0.08)$ & $(0.08)$ & $(0,14)$ & $(0.09)$ \\
\hline \multirow{2}{*}{ const } & & $16.1^{* * *}$ & $20.8^{* * *}$ & $12.6^{* * *}$ \\
\hline & & $(2.1)$ & $(3,3)$ & $(1,6)$ \\
\hline $\mathrm{n}$ & 57 & 57 & 24 & 33 \\
\hline $\mathrm{R}^{2}$ & 0.33 & 0.33 & 0.52 & 0.38 \\
\hline Corrected $\mathrm{R}^{2}$ & 0.21 & 0.21 & 0.39 & \\
\hline
\end{tabular}

Standard errors are specified in parentheses.

${ }^{*}$ significant at a 10 percent level.

** significant at a 5 percent level.

$* * *$ significant at a 1 percent level.

$* * * *$ model with the constant and slack variables COUNTRY_GROUPED_DEV,

COUNTRY_GROUPED_EU, COUNTRY_GROUPED_UK, the variable COUNTRY_GROUPED_US is eliminated.

For other regions, individually and collectively, the calculations indicate that all coefficients (except for the constant) are insignificant. For emerging markets the risk variable ESG_RISK_RTG is significant at a 5\% level and negative. The value of the correlation coefficient $\mathrm{R}^{2}$ increased a little while the absolute value is greater than in the general model.

The interpretation of the obtained results is ambiguous. On the one part, the result indicates that the "greener" and socially more responsible the company the greater EV/EBITDA is, i.e. the bigger the company value with the same profit. On the other part, the extent of explanation of changes of the dependent variable in the model is rather low and is explained by a rough division into groups which still have differences. A more serious group detailing as well as testing of the variables of ESG_RISK_RTG.COUNTRY_GROUP_... were not performed because it results in increase of the number of variables while the data set is highly limited. Besides, incompleteness of data should be taken into consideration because we tested only the companies in the ESG rating compiled by Sustainanalitics and a large number of companies have been eliminated because data was unfit for calculations.

The calculations indicate that everywhere the constants characterizing country differences become consistently significant coefficients while the coefficients characterizing components of corporate cash flow are mainly insignificant. In this case there may be a significant role of the fact that identical total cash flows may be divided into components in different ways. This may result in a wide scat- 
ter of regression coefficients, on the one hand, and, on the other hand, it is insignificant from the point of view of the explained variable. Therefore it is reasonable to introduce such variable as theoretically defined total cash flow or theoretically defined cost of capital. But we may simplify the problem as follows: probably, dependence of the cash flows components is not so important because the explained variable EV/EBITDA has the meaning of the period within which the cost of capital returns (actually it is the payback period) which should correspond to some mean values for a certain economy and industry.
We used for calculations a changed data set with an adjusted distribution by countries: we combined European countries (EU) with Great Britain, a part of countries representing emerging and risky markets was transferred to developed markets (New Zealand, South Korea, Taiwan). For this model we made calculations taking into consideration and not taking into consideration the variables which are components of cash flow (Table 3).

Table 3. Least-squares estimate of the changed model, GRETL package

Model: least square method, observations 1-57 were used

Dependent variable: EV_EBITDA

Robust estimators of standard errors (adjusted to heteroscedasticity), version HC1

\begin{tabular}{|c|c|c|c|c|}
\hline & Coefficient & Standard error & t statistics & P value \\
\hline ESG_RISK_RTG & -0.16 & 0.06 & -2.8 & $0.0083^{* * *}$ \\
\hline COUNTRY_GROUPED_DEV & 13.2 & 1.5 & 8.6 & $3.1 \mathrm{e}-011^{* * *}$ \\
\hline COUNTRY_GROUPED_EM & 11.6 & 1.6 & 7.1 & $4.6 \mathrm{e}-09^{* * *}$ \\
\hline COUNTRY_GROUPED_EU & 11.7 & 1.4 & 8.3 & $8.1 \mathrm{e}-011^{* * *}$ \\
\hline COUNTRY_GROUPED_US & 14.9 & 1.7 & 8.6 & $2.3 \mathrm{e}-011^{* * *}$ \\
\hline EBITDA_3Y_GROWTH & -0.5 & 0.32 & -1.7 & $0.099^{*}$ \\
\hline DEPR_EBITDA & 0.03 & 2.8 & 0.01 & 0.99 \\
\hline CAPEX_EBITDA & 2.6 & 1.6 & 1.6 & 0.16 \\
\hline NWC_EBITDA & 0.013 & 0.97 & 0.013 & 0.99 \\
\hline
\end{tabular}

Mean of dependent variable 6.968421

Standard deviation of the dependent variable 2.402957

Sum of squared errors $\quad 202.4249$

R square $\quad 0.373986$

$\mathrm{F}(8,48) \quad 96.55249$

Standard error of the model $\quad 2.053579$

Loglikelihood -116.9981

Corrected R square $\quad 0,269650$

Schwarz criterion 270.3836

$P$ value $(F) \quad 6.36 \mathrm{e}-27$

Akaike criterion $\quad 251.9961$

Hannan-Quinn criterion 259.1421

The biggest $\mathrm{p}$ value was obtained for variable 4 (DEPR_EBITDA)

\section{Redundant variables test-}

Zero hypothesis: regression parameters are zero parameters for the following variables:

EBITDA_3Y_GROWTH

DEPR_EBITDA

CAPEX_EBITDA

NWC_EBITDA

Test statistics: $\mathrm{F}(4,48)=4.34434$

$\mathrm{p}$ value $=\mathrm{P}(\mathrm{F}(4,48)>4.34434)=0.00444162$ 


\section{Redundant variables test -}

Zero hypothesis: regression parameters are zero parameters for the following variables:

DEPR_EBITDA

CAPEX_EBITDA

NWC_EBITDA

Test statistics: $\mathrm{F}(3,48)=4.99359$

$\mathrm{p}$ value $=\mathrm{P}(\mathrm{F}(3,48)>4.99359)=0.00428354$

\section{Redundant variables test -}

Zero hypothesis: regression parameters are zero parameters for the following variables: DEPR_EBITDA

Test statistics: $\mathrm{F}(1,48)=0.000139819$

$\mathrm{p}$ value $=\mathrm{P}(\mathrm{F}(1,48)>0.000139819)=0.990615$

\section{Redundant variables test -}

Zero hypothesis: regression parameters are zero parameters for the following variables:

DEPR_EBITDA

NWC_EBITDA

Test statistics: $\mathrm{F}(2,48)=0.00250273$

$\mathrm{p}$ value $=\mathrm{P}(\mathrm{F}(2,48)>0.00250273)=0.997501$

\section{Redundant variables test -}

Zero hypothesis: regression parameters are zero parameters for the following variables:

EBITDA_3Y_GROWTH

DEPR_EBITDA

NWC_EBITDA

Test statistics: $\mathrm{F}(3,48)=1.03322$

$\mathrm{p}$ value $=\mathrm{P}(\mathrm{F}(3,48)>1.03322)=0.386329$

\section{Redundant variables test -}

Zero hypothesis: regression parameters are zero parameters for the following variables:

NWC_EBITDA

Test statistics: $\mathrm{F}(1,48)=0.000166512$

$\mathrm{p}$ value $=\mathrm{P}(\mathrm{F}(1,48)>0.000166512)=0.989758$

\section{Redundant variables test -}

Zero hypothesis: regression parameters are zero parameters for the following variables:

\section{CAPEX_EBITDA}

Test statistics: $\mathrm{F}(1,48)=2.57559$

$\mathrm{p}$ value $=\mathrm{P}(\mathrm{F}(1,48)>2.57559)=0.115084$

The test of the changed model for redundant variables - cash flow components - was negative: the zero hypothesis that coefficients of the variables EBITDA_3Y_GROWTH, DEPR_EBITDA, CAPEX_EBITDA, NWC_EBITDA equal zero simultaneously should be rejected (Table 4). Consequently, the assumption that the EV/EBITDA variable does not depend on components of cash flow was not confirmed.

But the redundant variables test shows that 3 variables DEPR_EBITDA, NWC_EBITDA and EBITDA_3Y_GROWTH may be considered redundant. Therefore, we are going to consider a model with 3 less variables. Reduction in the number of variables allows to refine the model replacing such variables as ESG_RISK_RTG and CAPEX_EBITDA with xx.COUNTRY_GROUPED_yy variables where $\mathrm{xx}$ is ESG_RISK_RTG or CAPEX_EBITDA, COUNTRY_GROUPED yy is a slack variable denoting a group of countries (COUNTRY_GROUPED_DEV, COUNTRY_GROUPED_EM, COUNTRY_GROUPED_EU, COUNTRY_GROUPED_US). 
Regression equation:

EV_EBITDA =

c11.COUNTRY_GROUPED_DEV + c12.COUNTRY_GROUPED_EM + c13.COUNTRY_GROUPED_EU

+ c14.COUNTRY_GROUPED_US + c21·CAPEX_EBITDA.COUNTRY_GROUPED_DEV +

c22. CAPEX_EBITDA.COUNTRY_GROUPED_EM + c23·CAPEX_EBITDA.COUNTRY_GROUPED_EU

+ c24.CAPEX_EBITDA.COUNTRY_GROUPED_US + c31·ESG_RISK_RTG.COUNTRY_GROUPED_

DEV + c32·ESG_RISK_RTG·COUNTRY_GROUPED_EM + c33·ESG_RISK_RTG.COUNTRY_

GROUPED_EU + c34.ESG_RISK_RTG.COUNTRY_GROUPED_US.

Table 4. Least-squares estimate of a new changed model, GRETL package

Model 15: least square method, observations 1-57 were used

Dependent variable: EV_EBITDA

Robust estimators of standard errors (adjusted to heteroscedasticity), version HC1

\begin{tabular}{|c|c|c|c|c|c|}
\hline Coefficient & Variable & Coefficient value & Standard error & T statistics & P value \\
\hline $\mathrm{c} 11$ & $\begin{array}{l}\text { COUNTRY_ } \\
\text { GROUPED_DEV }\end{array}$ & 15.7 & 3.1 & 5.1 & $<0.0001^{\star * *}$ \\
\hline $\mathrm{c} 12$ & $\begin{array}{l}\text { COUNTRY_- } \\
\text { GROUPED_EM }\end{array}$ & 10.1 & 4.3 & 2.4 & $0.02^{* *}$ \\
\hline $\mathrm{c} 13$ & $\begin{array}{l}\text { COUNTRY_- } \\
\text { GROUPED_EU }\end{array}$ & 13.2 & 3.1 & 4.2 & $0.0001^{\star * *}$ \\
\hline c14 & $\begin{array}{l}\text { COUNTRY_- } \\
\text { GROUPED_US }\end{array}$ & 11.0 & 3.0 & 3.6 & $0.0007^{* * *}$ \\
\hline $\mathrm{c} 21$ & CAPEX_EBITDA_DEV & 1.5 & 1.0 & 1.6 & 0.1 \\
\hline c22 & CAPEX_EBITDA_EM & 0.6 & 1.8 & 0.3 & 0.7 \\
\hline c23 & CAPEX_EBITDA_EU & 5.9 & 2.4 & 2.4 & $0.02^{\star *}$ \\
\hline c24 & CAPEX_EBITDA_US & 5.8 & 1.6 & 3.7 & $0.0006^{* * *}$ \\
\hline $\mathrm{c} 31$ & ESG_DEV & -0.31 & 0.14 & -2.2 & $0.03^{* *}$ \\
\hline $\mathrm{c} 32$ & ESG_EM & -0.159 & 0.157 & -1.0 & 0.3 \\
\hline c33 & ESG_EU & -0.18 & 0.09 & -1.9 & $0.06^{*}$ \\
\hline c34 & ESG_US & 0.05 & 0.14 & 0.34 & 0.74 \\
\hline & $\begin{array}{l}\text { Mean of the dependent } \\
\text { variable }\end{array}$ & 6.968421 & \multicolumn{2}{|c|}{$\begin{array}{l}\text { Standard deviation of the } \\
\text { dependent variable }\end{array}$} & 2.402957 \\
\hline & Sum of squared errors & 195.0347 & \multicolumn{2}{|c|}{ Standard error of the model } & 2.081851 \\
\hline & $\mathrm{R}$ square & 0.396841 & \multicolumn{2}{|c|}{ Corrected R square } & 0.249402 \\
\hline & $F(11,45)$ & 128.9302 & \multicolumn{2}{|l|}{$P$ value $(F)$} & $3.22 \mathrm{e}-30$ \\
\hline & Loglikelihood & -115.9381 & \multicolumn{2}{|l|}{ Akaike criterion } & 255.8762 \\
\hline & Schwarz criterion & 280.3928 & \multicolumn{2}{|c|}{ Hannan-Quinn criterion } & 265.4042 \\
\hline
\end{tabular}

Calculation of this model shows that there is dependence between the risk value of environmental, social responsibility and corporate governance factors of the considered ESG rating and the EV/EBITDA parameter which characterizes the cost of capital, i.e. the lower the risk, the greater the cost of capital (a coefficient preceding the ESG_yy variable is negative). 
For various country groups the abovementioned result was obtained with different degrees of reliability: for "other developed countries" (DEV) with a high 5\% significance level, for European countries - with a 10\% level. For the USA insignificance of the coefficient is associated with a small sample size. For developing country markets (EM) the coefficient is insignificant. A difference for the EM group from the results obtained in the previous model (equation (1)) is ostensible because in the new model the key players representing New Zealand, South Korea and Taiwan are transferred to the group of "other developed countries" DEV. Other countries pertaining to the group are diverse. This, together with the reduced number of observations in the group after transfer of a part of countries to the DEV group, leads to greater values of the standard error and as a result - to insignificance of the $\mathrm{c} 32$ coefficient.

On the basis of the results of this research it is shown that taking of ESG risk factors into consideration by a company helps to make a more accurate business evaluation by means of using the EV/EBITDA parameter which is confirmed by empiric results for telecommunications companies. This may be useful from the economic point of view to concerned parties in developed markets, in particular, in European markets. Thus, the fact that enterprises pay increasingly more attention to the environment and the influence they produce on the society becomes undeniable. In light of this, the present research should enhance investors' confidence in companies with an actual progress in ESG.

Our research conclusions indicate that companies' efforts of ensuring a sustainable development facilitate a successful conduct of business, providing solution of social problems at the same time. Thus, elimination of ESG risks increases corporate competitive strength. As long as in some countries companies are under no obligation to disclose ESG information results of this research may encourage companies to consider non-financial disclosure as an important indicator of long-term sustainability. When ESG is considered as an integral factor of corporate future operations the final outcome is a higher evaluation of the company by stakeholders.

\section{References}

1. Wu T.C., Tsaur C.C., Lin C.H., Shiau S.Y. Surveying safety culture in telecommunications industry. Journal of Occupational Safety and Health. 2011;4(19):403-420.

2. Ruiz-Canela López J. How can enterprise risk management help in evaluating the operational risks for a telecommunications company? Journal of Risk and Financial Management. 2021;14(3):139. https:// doi.org/10.3390/jrfm14030139

3. Yesuf A.S. A review of risk identification approaches in the telecommunication domain. In: Proc. $3^{\text {rd }}$ Int. conf. on information systems security and privacy (ICISSP 2017). (Porto, Feb. 19-21, 2017).
Lisboa: INSTICC; 2017:389-396. https://doi. org/10.5220/0006197603890396

4. Gandini G., Bosetti L., Almici A. Risk management and sustainable development of telecommunications companies. Symphonya: Emerging Issues in Management. 2014;(2):16-29. http://dx.doi. org/10.4468/2014.2.03gandini.bosetti.almici

5. Pakhchanyan S. Operational risk management in financial institutions: A literature review. International Journal of Financial Studies. 2016;4(4):20. https://doi.org/10.3390/ijfs4040020

6. MacDonald D.B. When risk management collides with enterprise sustainability. Journal of Leadership, Accountability \& Ethics. 2011;8(3):56-66.

7. Salvioni D.M. Governance, risk management and business effectiveness in global firm. In: Tipurić D., Dabić M., eds. Management, governance, and entrepreneurship: New perspective and challenges. Darwen: Access Press; 2012.

8. McShane M.K., Nair A., Rustambekov E. Does enterprise risk management increase firm value? Journal of Accounting, Auditing and Finance. 2011;26(4):41-58. https://doi. org/10.1177/0148558X11409160

9. Monda B., Giorgino M. An ERM maturity model. In: 2013 Enterprise risk management symposium (Chicago, Apr. 22-24, 2013). Schaumburg, IL: Society of Actuaries; 2013. URL: https://web.actuaries.ie/ sites/default/files/erm-resources/50_ERM_maturity_ model.pdf.pdf

10. Kumar P.C. ESG compliant companies provide superior returns. The Star. Feb. 29, 2020. URL: https://www.thestar.com.my/business/businessnews/2020/02/29/esg-compliant-companies-providesuperior-returns

11. Friede G., Busch T., Bassen A. ESG and financial performance: Aggregated evidence from more than 2000 empirical studies. Journal of Sustainable Finance and Investment. 2015;5(4):210-233. https://doi.org/10. $1080 / 20430795.2015 .1118917$

12. Noronha C., Guan J., Fan J. Firm value and social contribution with the interaction of corporate governance: Social contribution value per share. Sustainability Accounting, Management and Policy Journal. 2018;9(2):165-200. https://doi.org/10.1108/ SAMPJ-10-2016-0078

13. Buallay A. Is sustainability reporting (ESG) associated with performance? Evidence from the European banking sector. Management of Environmental Quality. 2019;30(1):98-115. https://doi.org/10.1108/ MEQ-12-2017-0149

14. Porter M., Serafeim G., Kramer M. Where ESG fails. Institutional Investor. Oct. 16, 2019. URL: 
https://www.institutionalinvestor.com/article/ b1hm5ghqtxj9s7/Where-ESG-Fails

15. Duque-Grisales E., Aguilera-Caracuel J.

Environmental, social and governance ESG scores and financial performance of multinationals: Moderating effects of geographic international diversification and financial slack. Journal of Business Ethics. 2021;168(2):315-334. https://doi.org/10.1007/ s10551-019-04177-w

16. Radhouane I., Nekhili M., Nagati H., Paché G. Is voluntary external assurance relevant for the valuation of environmental reporting by firms in environmentally sensitive industries? Sustainability Accounting, Management and Policy Journal. 2020;11(1):65-98. https://doi.org/10.1108/ SAMPJ-06-2018-0158

17. Buallay A., Fadel S.M., Alajmi J., Saudagaran S. Sustainability reporting and bank performance after financial crisis: evidence from developed and developing countries. Competitiveness Review. 2021;31(4):747-770. https://doi.org/10.1108/CR-042019-0040

18. Saurabh S. Economic value added for competitive advantage: A case of Indian enterprises. Newcastle upon Tyne: Cambridge Scholars Publishing; 2019. $176 \mathrm{p}$.

19. Khorin A., Bulgakov A., Krikunov A. Financial effects of corporate social responsibility and information transparency: Research in the pharmaceutical industry. Korporativnye finansy = Journal of Corporate Finance Research. 2020;14(1):29-38. https://doi. org/10.17323/j.jcfr.2073-0438.14.1.2020.29-38

20. Bulgakov A. Big Data in finance. Korporativnye finansy = Journal of Corporate Finance Research. 2017;11(1):7-15. (In Russ.). https://doi. org/10.17323/j.jcfr.2073-0438.11.1.2017.7-15

21. Company ESG risk ratings. Morningstar Company. Sustainalytics. URL: https://www.sustainalytics.com/ esg-ratings (accessed on 30.06.2021).

Contribution of the authors: the authors contributed equally to this article.

The authors declare no conflicts of interests.

The article was submitted 12.11.2021; approved after reviewing 14.11.2021; accepted for publication 16.11.2021. 